\title{
Determination of Phenolic Compounds in Adzuki bean (Vigna angularis) Germplasm
}

\author{
Eun Hye Kim*, Hong Keun Song*, Yong Jin Park**, Jeong Ran Lee***, Min Young Kim*, and III-Min Chung* \\ *Department of Applied Life science, College of Life \& Environmental Sciences, Konkuk University, Seoul 143-701, Korea \\ **Department of Plant Resources, Kongju University, Yesan 340-702, Korea \\ ***National Academy of Agricultural Science, RDA, Suwon 441-857, Korea
}

\begin{abstract}
The aim of this study was to evaluate 30 phenolic compounds in adzuki bean germplasm. Adzuki 21653 had the highest content of total phenolics compounds $\left(6597 \mu \mathrm{g} \mathrm{g}^{-1}\right)$ while 104372 had the lowest concentration. The average total phenolic content of Japanese $\left(2432 \mu \mathrm{g} \mathrm{g}^{-1}\right)$ adzuki beans was higher than that of Korean $\left(2256 \mu \mathrm{g} \mathrm{g}^{-1}\right)$ adzuki beans. The average total phenolic contents were $2507 \mu \mathrm{g} \mathrm{g}^{-1}$ in small sized adzuki beans from Japan and $2459 \mu \mathrm{g} \mathrm{g}^{-1}$ in those from Korea. In large sized adzuki beans, the average total phenolic contents were $1315 \mu \mathrm{g} \mathrm{g}^{-1}$ in Japanese seeds and $1232 \mu \mathrm{g} \mathrm{g}^{-1}$ in Korean seeds. The average total phenolic contents in medium seeds were 2369 $\mu \mathrm{g} \mathrm{g}^{-1}$ in Japanese adzuki beans and $1397 \mu \mathrm{g} \mathrm{g}^{-1}$ in Korean ones. In small seeds, the total phenolic contents of adzuki beans varied from $524 \mu \mathrm{g} \mathrm{g}^{-1}$ to $6597 \mu \mathrm{g} \mathrm{g}^{-1}$ in Japanese ones and from $375 \mu \mathrm{g} \mathrm{g}^{-1}$ to $6569 \mu \mathrm{g} \mathrm{g}^{-1}$ in Korean ones. Japanese and Korean adzuki beans were divided into landraces and wild adzuki beans. In this study, the wild adzuki beans showed higher contents of total phenolics than the native varieties. Specifically, the wild adzuki beans from Korea had the highest concentration of phenolics (3403 $\mu \mathrm{g} \mathrm{g}^{-1}$ ). All adzuki bean germplasms were measured for their color and were classified into four groups accordingly: $\mathrm{A} ; \mathrm{L}<30,+\mathrm{a},+\mathrm{b} ; \mathrm{B} ; \mathrm{L}<30,+\mathrm{a},-\mathrm{b}, \mathrm{C} ; \mathrm{L}>50,+\mathrm{a},+\mathrm{b}$, $\mathrm{D} ; \mathrm{L}>50,+\mathrm{a},-\mathrm{b}$. Especially, group $\mathrm{B}$ had the highest concentration of total phenolic compounds $\left(2827 \mu \mathrm{g} \mathrm{g}^{-1}\right)$, whereas group $\mathrm{C}$ had the lowest concentration $\left(1882 \mu \mathrm{g} \mathrm{g}^{-1}\right)$.
\end{abstract}

Keywords : adzuki bean germplasm; phenolic compounds

Leguminous seeds are an important source of nutrient compounds, such as starch, protein, dietary fiber and minerals (Geil and Anderson, 1994). Adzuki beans are a leguminous crop as well as a popular material in various confections. The consumption of adzuki beans is concentrated in Asia, where the bean has its most important economic value (Yoshida et al., 2008).

Carbohydrates are the major compound in adzuki beans, which also contains fiber, protein, vitamins, and minerals (Tjahjadi et al., 1988). In Asia, boiled adzuki bean juice has been used as a folk remedy to prevent damage associated with aging (Maruyama et al., 2008).

Phenolic compounds have an aromatic ring bearing one or more hydroxy groups (Kim et al., 2006). They are known to present strong antioxidant, anti-mutagenic, and anti-genotoxic activities, which have beneficial effects on humans (Rice-Evans et al., 1996).

The major phenolic compounds include phenolic acids and flavonoids. Flavonoids show differences and variations during ripening and harvesting (Raffo et al., 2004). The antioxidant activities of legumes depends on the variety of the plant and observed variously (Amarowicz and Pegg, 2008).

Previous studies have reported that the phenolic content changes remarkably during the ripening process (Amiot et al., 1986; Romero et al., 2002; Bouaziz et al., 2004). Further, cultivar and altitude are important factors that affect the phenolic content (Blekas et al., 2002). There have been many studies on phenolic compounds in leguminous plants (Shon et al., 2007).

In this study, the phenolic compounds contents of adzuki bean germplasms were analyzed by HPLC. Although adzuki beans are a valuable crop, there has not been sufficient research on their functional materials and characteristics. Thus, this study aims to provide helpful information for breeders and the food industry.

\footnotetext{
${ }^{\dagger}$ Corresponding author: (Phone) +82-2-450-3730 (E-mail) imcim@konkuk.ac.kr

$<$ Received 2 November 2011; Revised 9 November 2011; Accepted 21 November 2011>
} 


\section{MATERIALS AND METHODS}

\section{Preparation of adzuki bean germplasm}

A total of 150 adzuki bean germplasms were donated from the gene bank of the RDA (Rural Development Administration, Suwon, Gyeonggi-Do, Korea). They were divided into two groups according to origin (Japan and Korea) and 100 seed weight (small $(<12 \mathrm{~g})$, medium (12 18 g), and large (> $18 \mathrm{~g})$ seeds) (Fig. 1) as shown in Appendix 1.

We determined the color values (L: lightness $(0=$ black, $100=$ white $), a(-a=$ greenness, $+\mathrm{a}=$ redness $), \mathrm{b}(-\mathrm{b}=$ blueness, $+b=$ yellowness)) of the 150 adzuki bean germplasms, and the instrumentation used was a Minolta Color Difference Meter (Model CR-310, Minolta Co. Ltd,

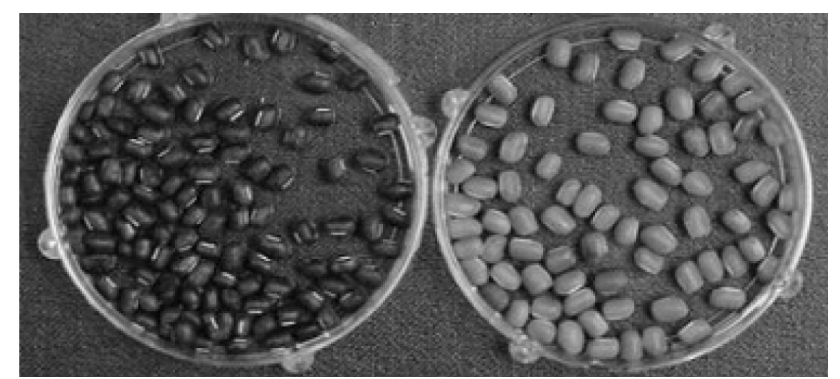

Small

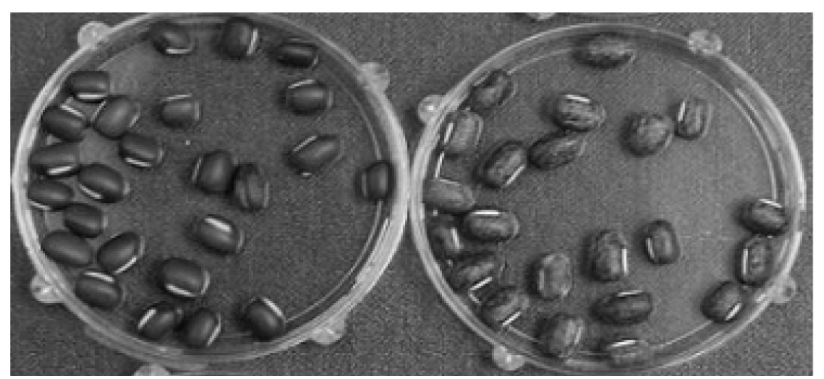

Medium

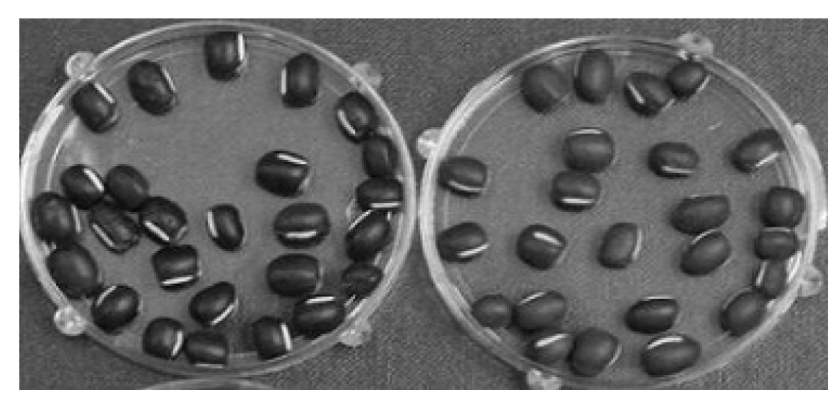

Large

Fig. 1. Seeds of adzuki bean germplasm seeds sorted by seed size.
Osaka, Japan). Calibration was carried out on a standard white plate. All samples were measured three times and classified into four groups according to their color values. The categorization of colors in adzuki beans followed Hunter's color values and is shown in Table 1. The mean color values of adzuki beans from Japan and Korea according to seed size are shown in Table 2 .

\section{Analysis of phenolic compounds in adzuki bean}

Each adzuki bean seed was dried in a freeze-dryer under vacuum conditions (Freezeone 4.5, Labconco, Kansas, Missouri, USA) and then ground up. In this study, methanol (100\%), acetonitrile (100\%), glacial acetic acid (99.9\%), and distilled water were purchased from J. T. Baker (HPLC grade, USA), and hydrochloric acid was purchased from Daejung Co. (Daejung Chemical \& Materials Co. Ltd, Siheung, Gyeonggi-Do, Korea). Dimethyl sulfoxide (DMSO), gallic acid, pyrogallol, homogentisic acid, protocatechuic acid, gentisic acid, chlorogenic acid, (+)catechin, $p$-hydroxybenzoic

Table 1. Categorization of colors in adzuki bean germplasm.

\begin{tabular}{cccc}
\hline \hline Group & $\mathrm{L}$ (Lightness) & $\mathrm{a}$ (Redness) & $\mathrm{b}$ (Yellowness) \\
\hline $\mathrm{A}$ & $\mathrm{L}<30$ & $+\mathrm{a}$ & $+\mathrm{b}$ \\
$\mathrm{B}$ & $\mathrm{L}<30$ & $+\mathrm{a}$ & $-\mathrm{b}$ \\
$\mathrm{C}$ & $\mathrm{L}>50$ & $+\mathrm{a}$ & $+\mathrm{b}$ \\
$\mathrm{D}$ & $\mathrm{L}>50$ & $+\mathrm{a}$ & $-\mathrm{b}$ \\
\hline
\end{tabular}

Table 2. Color comparison between Japanese and Korean adzuki beans of different size.

\begin{tabular}{clcc}
\hline \hline Origins & & Japan & Korea \\
\hline \multirow{5}{*}{ Small } & Number of variety & 51 & 43 \\
& Light & 25.6 & 47.3 \\
& Redness & 1.9 & 3.4 \\
& Yellowness & 0.7 & 0.6 \\
\hline \multirow{5}{*}{ Medium } & Number of variety & 6 & 10 \\
& Light & 25.7 & 51.5 \\
& Redness & 3.4 & 5.0 \\
& Yellowness & 0.6 & 1.7 \\
\hline \multirow{5}{*}{ Large } & Number of variety & 4 & 2 \\
& Light & 25.8 & 39.8 \\
& Redness & 4.9 & 1.3 \\
& Yellowness & 1.3 & -0.6 \\
\hline
\end{tabular}


acid, $\beta$-resorcylic acid, vanillic acid, caffeic acid, syringic acid, vanillin, $p$-coumaric acid, rutin, ferulic acid, veratric acid, $m$-coumaric acid, naringin, hesperedin, $o$-coumaric acid, myricetin, resveratrol, quercetin, $t$-cinnamic acid, naringenin, kaempferol, hesperetin, formononetin, and biochanin A were purchased from Sigma-Aldrich (USA).

Extraction of phenolic compounds from adzuki bean samples followed the method of Wang and Murphy (1994). The extraction solvent was composed of $10 \mathrm{~mL}$ of acetonitrile and $2 \mathrm{~mL}$ of $0.1 \mathrm{~N}$ hydrochloric acid per sample. The ground samples $(2 \mathrm{~g})$ were extracted with extraction solvent, followed by stirring for $2 \mathrm{~h}$ at room temperature (GreenSseriker, Vision Scientific Co. Ltd, Bucheon, Gyeonggi-Do, Korea). The extract was filtered through No. 42 Whatman filter paper $(125 \mathrm{~mm} \times 100$ circles, Maidstone, England) and concentrated using a vacuum evaporator (EYELA, Tokyo Rikakikai, Co. Ltd, Japan) below $40^{\circ} \mathrm{C}$. The residues were redissolved with $10 \mathrm{~mL}$ of $100 \%$ aqueous methanol (HPLC grade, J. T. Baker, USA), filtered through a $0.2 \mu \mathrm{m}$ nylon membrane syringe filter $(17 \mathrm{~mm}$, TITAN, Sunsri, Rockwood, Tennessee, USA), and transferred into a $2 \mathrm{~mL}$ vial, followed by analysis by HPLC.

The HPLC system used was an Agilent 1100 (Palo Alto, CA, USA) series system equipped with a photodiode array (PDA) detector. Separation was primarily achieved using a YMC-Pack ODS AM-303 (5 $\mu \mathrm{m}, 250 \mathrm{~mm} \times 4.6 \mathrm{~mm}$ I.D. $)$ column. The absorbance was measured at $280 \mathrm{~nm}$. HPLC analysis was applied by following the modified method of Kim et al. (2006). The mobile phases were $0.1 \%$ glacial acetic acid in distilled water (solvent A) and was $0.1 \%$ glacial acetic acid in acetonitrile (solvent B). The injection volume was $20 \mu \mathrm{l}$, and the gradient was as follows: $0 \mathrm{~min}$, $92 \%$ A : 8\% B; 0 2 min 90\% A : $10 \%$ B; 2 27 min, 70\% A: $30 \% \mathrm{~B} ; 27 \sim 50 \mathrm{~min}, 10 \% \mathrm{~A}: 90 \% \mathrm{~B} ; 50 \sim 51 \mathrm{~min}, 0 \%$ $\mathrm{A}: 100 \% \mathrm{~B} ; 51 \sim 60 \mathrm{~min}, 0 \% \mathrm{~A}: 100 \% \mathrm{~B} ; 60 \sim 63 \mathrm{~min}$, $92 \%$ A : $8 \%$ B. The run time was 63 min and flow rate $1 \mathrm{~mL} \mathrm{~min}{ }^{-1}$. Genuine standards of 30 phenolic compounds were made in dimethyl sulfoxide and used to establish calibration curves.

Phenolic compounds in adzuki beans were determined based on the retention times of the standards, and the plotting standard concentration was obtained at several concentrations, $25,50,100,150 \mu \mathrm{g} \mathrm{mL}^{-1}$. High linearity of $\mathrm{r}^{2}>0.996$ was obtained from each curve.

\section{RESULTS AND DISCUDSSION}

\section{Phenolic compounds in the adzuki bean germplasm}

A total of 150 adzuki beans, or red beans, were donated by the gene bank of the RDA (Rural Development Administration, Suwon, Gyonggi-Do, Korea). Among them, 112 adzuki beans were divided into two groups according to their country of origin (Japan and Korea). In addition, they were classified into four groups according to color (Table 1, Table 2). Statistical analyses were conducted by the general linear model procedure (GLM) of 2005 SAS package (Version 9.1, SAS Inst. Inc. Cary, N.C., USA). The experimental design was a completely randomized design (CRD) with duplicates. Least significant difference (LSD) test was based on a 0.05 probability level.

The total phenolic content was the highest in 216530 (Appendix 1) adzuki bean (6596.9 $\left.\mu \mathrm{g} \mathrm{g}^{-1}\right)$ while germplasm 104372 had the lowest concentration. The average total phenolic content of Japanese adzuki beans was higher (2432.4 $\left.\mu \mathrm{g} \mathrm{g}^{-1}\right)$ than that of Korean adzuki beans $\left(2255.5 \mu \mathrm{g} \mathrm{g}^{-1}\right)$ (Fig. 2).

Figure 3 shows a comparison of the total phenolic content between small, medium, and large sized adzuki beans from Japan and Korea. The mean total phenolic content in small

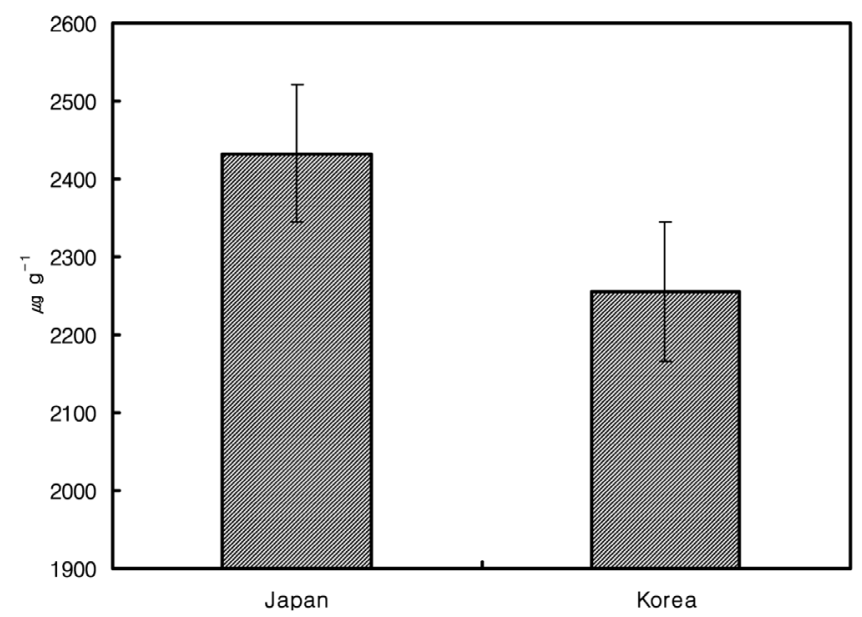

Fig. 2. Comparison of average total phenolic contents between Korean and Japanese adzuki beans of two different regions. Statistical significance was analyzed by least significant difference $(\mathrm{LSD})(\mathrm{p}<0.05)$. 


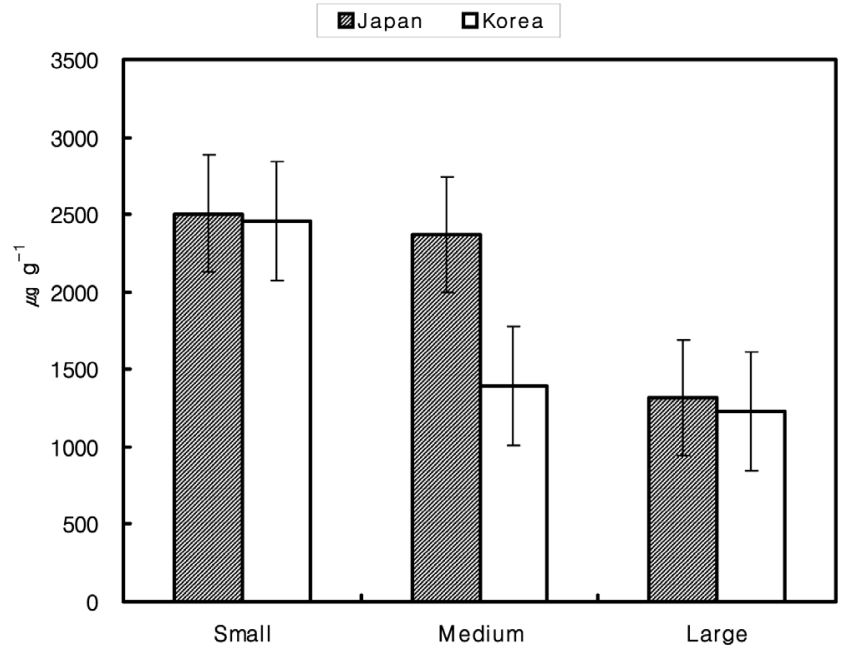

Fig. 3. Average total phenolic contents in small, medium, and large seeds of Japanese and Korean adzuki bean germplasms. Statistical significance was analyzed by least significant difference (LSD) $(\mathrm{p}<0.05)$.

(Small seed: < $12 \mathrm{~g}$, Medium seed: 12 18 g, Large seed: $>18 \mathrm{~g})$

adzuki beans from Japan was $2506.6 \mu \mathrm{g} \mathrm{g}^{-1}$, whereas that in Korean seeds was $2458.8 \mu \mathrm{g} \mathrm{g}^{-1}$.

In large adzuki beans, the mean total phenolic contents were $1315.1 \mu \mathrm{g} \mathrm{g}^{-1}$ in Japanese adzuki bean seeds and $1231.9 \mu \mathrm{g} \mathrm{g}^{-1}$ in Korean ones. The average total phenolic contents in medium seeds were $2368.6 \mu \mathrm{g} \mathrm{g}^{-1}$ in Japanese type and $1397.0 \mu \mathrm{g} \mathrm{g}^{-1}$ in Korean.

In small seeds, the total phenolic contents of adzuki beans ranged from $523.8 \mu \mathrm{g} \mathrm{g}^{-1}$ to $6596.9 \mu \mathrm{g} \mathrm{g}^{-1}$ in Japanese and from $374.5 \mu \mathrm{g} \mathrm{g}^{-1}$ to $6569.2 \mu \mathrm{g} \mathrm{g}^{-1}$ in Korean.

In medium seeds, the total phenolic contents varied from $609.4 \mu \mathrm{g} \mathrm{g}^{-1}$ to $3300.3 \mu \mathrm{g} \mathrm{g}^{-1}$ in Japanese adzuki beans and from $401.5 \mu \mathrm{g} \mathrm{g}^{-1}$ to $2825.7 \mu \mathrm{g} \mathrm{g}^{-1}$ in Korean ones. For large seeds, the concentrations of phenolic compounds were as follows: Japan (565.9 $\left.\mu \mathrm{g} \mathrm{g}^{-1} \sim 2591.3 \mu \mathrm{g} \mathrm{g}^{-1}\right)$ and Korea (466.2 $\mu \mathrm{g} \mathrm{g}^{-1} \sim 1997.7 \mu \mathrm{g} \mathrm{g}^{-1}$ ).

Small seeds from Japan (6596.9 $\left.\mu \mathrm{g} \mathrm{g}^{-1}\right)$ and Korea $\left(6569.2 \mu \mathrm{g} \mathrm{g}^{-1}\right)$ had the high levels of phenolic compounds, whereas large Korean adzuki beans had the lowest content (1231.9 $\left.\mathrm{g} \mathrm{g} \mathrm{g}^{-1}\right)$ (Table 3).

Specifically, Japanese and Korean adzuki bean germplasms were divided into landraces and wild adzuki beans (Table 4). Among the landraces, the average total phenolic contents
Table 3. Comparison of total phenolic content between small, medium, and large adzuki beans from Japan and Korea.

\begin{tabular}{|c|c|c|c|}
\hline Origins & & Japan & Korea \\
\hline \multirow{6}{*}{ Small } & Number of variety & 51 & 43 \\
\hline & Maximum $\left(\mu \mathrm{g} \mathrm{g}^{-1}\right)$ & 6596.9 & 6569.2 \\
\hline & Minimum $\left(\mu g g^{-1}\right)$ & 523.8 & 374.5 \\
\hline & Mean $\left(\mu \mathrm{g} \mathrm{g}^{-1}\right)$ & 2506.6 & 2458.8 \\
\hline & $\mathrm{CV}(\%)$ & 30.5 & 6.1 \\
\hline & $\operatorname{LSD}_{(0.05)}$ & 1532.5 & 303.5 \\
\hline \multirow{6}{*}{ Medium } & Number of variety & 6 & 10 \\
\hline & Maximum $\left(\mu \mathrm{g} \mathrm{g}^{-1}\right)$ & 3300.3 & 2825.7 \\
\hline & Minimum $\left(\mu g g^{-1}\right)$ & 609.4 & 401.5 \\
\hline & Mean $\left(\mu g g^{-1}\right)$ & 2368.6 & 1397.0 \\
\hline & $\mathrm{CV}(\%)$ & 9.4 & 1.3 \\
\hline & $\operatorname{LSD}_{(0.05)}$ & 546.4 & 41.8 \\
\hline \multirow{6}{*}{ Large } & Number of variety & 4 & 2 \\
\hline & Maximum $\left(\mu \mathrm{g} \mathrm{g}^{-1}\right)$ & 2591.3 & 1997.7 \\
\hline & Minimum $\left(\mu \mathrm{g} \mathrm{g}^{-1}\right)$ & 565.9 & 466.2 \\
\hline & Mean $\left(\mu \mathrm{g} \mathrm{g}^{-1}\right)$ & 1315.1 & 1231.9 \\
\hline & $\mathrm{CV}(\%)$ & 9.1 & 4.2 \\
\hline & $\operatorname{LSD}_{(0.05)}$ & 378.0 & 220.1 \\
\hline
\end{tabular}

Table 4. Comparison of average total phenolic content between adzuki bean landraces and wild adzuki beans from Japan and Korea.

\begin{tabular}{clcc}
\hline \hline Origins & & Japan & Korea \\
\hline \multirow{4}{*}{ Land } & Number of variety & 29 & 36 \\
& Maximum $\left(\mu \mathrm{g} \mathrm{g}^{-1}\right)$ & 3925.5 & 5242.5 \\
& Minimum $\left(\mu \mathrm{g} \mathrm{g}^{-1}\right)$ & 523.8 & 374.5 \\
& Mean $\left(\mu \mathrm{g} \mathrm{g}^{-1}\right)$ & 2088.8 & 1753.7 \\
& CV (\%) & 4.9 & 6.3 \\
& LSD (0.05) & 210.5 & 222.2 \\
\hline \multirow{6}{*}{ Wild } & Number of variety & 31 & 16 \\
& Maximum $\left(\mu \mathrm{g} \mathrm{g}^{-1}\right)$ & 6596.9 & 6569.2 \\
& Minimum $\left(\mu \mathrm{g} \mathrm{g}^{-1}\right)$ & 1532.8 & 842.3 \\
& Mean ( $\left.\mu \mathrm{g} \mathrm{g}^{-1}\right)$ & 2714.8 & 3404.3 \\
& CV (\%) & 36.0 & 5.4 \\
& LSD $(0.05)$ & 1993.0 & 391.4 \\
\hline
\end{tabular}

in adzuki bean germplasm from Japan and Korea were $2088.8 \mu \mathrm{g} \mathrm{g}^{-1}$ and $1753.7 \mu \mathrm{g} \mathrm{g}^{-1}$, respectively. In wild adzuki beans, the mean concentration of total phenolic compounds 


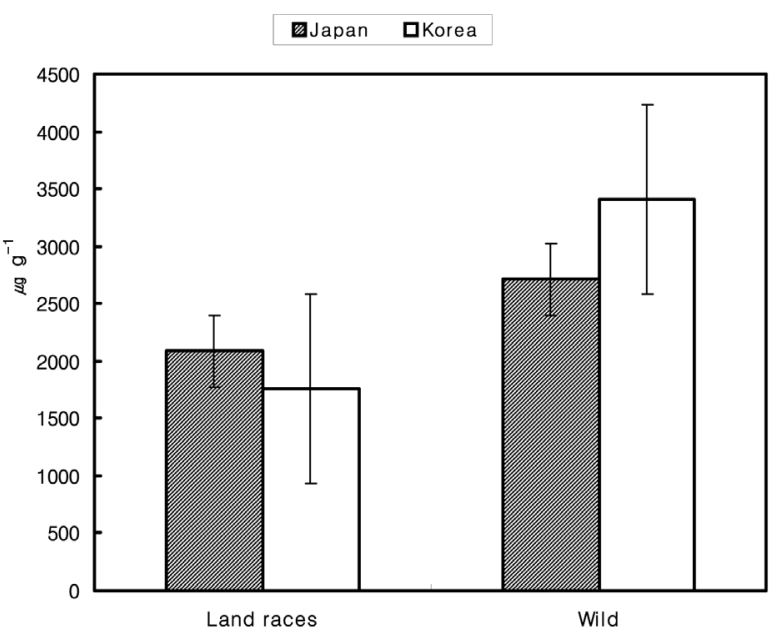

Fig. 4. Average phenolic contents of adzuki bean landraces and wild adzuki beans from Japan and Korea. Statistical significance was analyzed by least significant difference (LSD) $(\mathrm{p}<0.05)$.

was $2714.8 \mu \mathrm{g} \mathrm{g}^{-1}$ in those from Japan and $3404.3 \mu \mathrm{g} \mathrm{g}^{-1}$ in those from Korea. In this study, wild adzuki beans showed higher phenolic contents than the adzuki bean landraces (Fig. 4). Specifically, wild adzuki beans from Korea had the highest total phenolic content (3404.3 $\left.\mu \mathrm{g} \mathrm{g}^{-1}\right)$.

In adzuki bean landraces, the average total phenolic contents varied from $523.8 \mu \mathrm{g} \mathrm{g}^{-1}$ to $3925.5 \mu \mathrm{g} \mathrm{g}^{-1}$ in Japanese adzuki beans and from $374.5 \mu \mathrm{g} \mathrm{g}^{-1}$ to $5242.5 \mu \mathrm{g} \mathrm{g}^{-1}$ in Korean adzuki beans. On the other hand, in wild adzuki beans, the total average phenolic contents ranged from $1532.8 \mu \mathrm{g} \mathrm{g}^{-1}$ to $6596.9 \mu \mathrm{g} \mathrm{g}^{-1}$ in Japanese wild adzuki beans and from $842.3 \mu \mathrm{g} \mathrm{g}^{-1}$ to $6569.2 \mu \mathrm{g} \mathrm{g} \mathrm{g}^{-1}$ in Korean wild adzuki beans (Table 4).

Whole adzuki bean samples were measured for their color values and classified into four groups accordingly: A; $\mathrm{L}<30,+\mathrm{a},+\mathrm{b} ; \mathrm{B} ; \mathrm{L}<30,+\mathrm{a},-\mathrm{b}, \mathrm{C} ; \mathrm{L}>50,+\mathrm{a},+\mathrm{b}, \mathrm{D}$; $\mathrm{L}>50$, +a, -b.

In group $\mathrm{A}(\mathrm{L}<30,+\mathrm{a},+\mathrm{b})$, the average total phenolic content was $2439.1 \mu \mathrm{g} \mathrm{g}^{-1}, 2826.9 \mu \mathrm{g} \mathrm{g}^{-1}$ in group B $(\mathrm{L}<$ $30,+\mathrm{a},-\mathrm{b}), 1881.1 \mathrm{\mu g} \mathrm{g}^{-1}$ in the group $\mathrm{C}(\mathrm{L}>50,+\mathrm{a},+\mathrm{b})$, and $2184.2 \mu \mathrm{g} \mathrm{g}^{-1}$ in group $\mathrm{D}(\mathrm{L}>50,+\mathrm{a},-\mathrm{b})$.

Among the four color values, the concentration of phenolic compounds varied from $523.8 \mu \mathrm{g} \mathrm{g}^{-1}$ to $5642.3 \mu \mathrm{g} \mathrm{g}^{-1}$ in group $\mathrm{A}$, from $1689.0 \mu \mathrm{g} \mathrm{g}^{-1}$ to $6597.0 \mu \mathrm{g} \mathrm{g}^{-1}$ in B group, from $413.3 \mu \mathrm{g} \mathrm{g}^{-1}$ to $5242.5 \mu \mathrm{g} \mathrm{g}^{-1}$ in group $\mathrm{C}$, and from $374.5 \mu \mathrm{g} \mathrm{g}^{-1}$ to $5049.6 \mu \mathrm{g} \mathrm{g}^{-1}$ in group D. Especially,

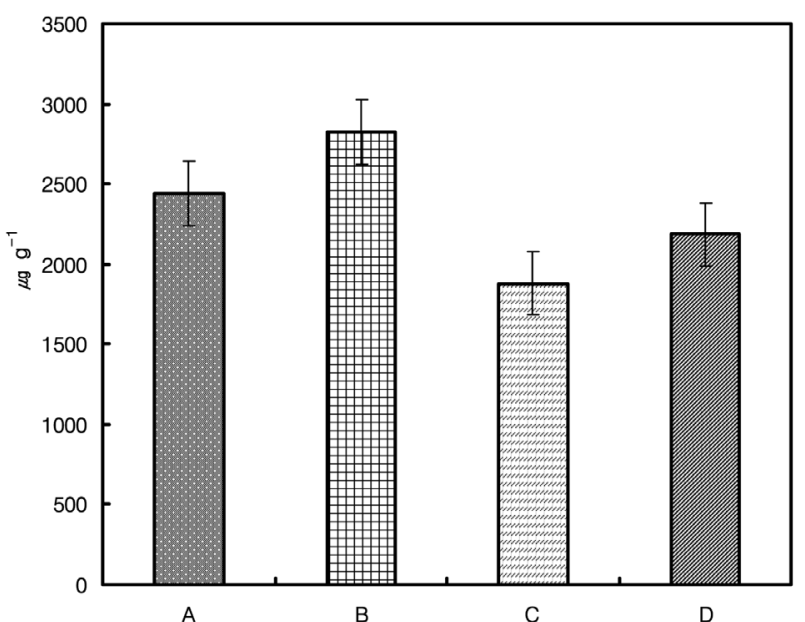

Fig. 5. Comparison of total phenolic content according to seed color value. Statistical significance was analyzed by least significant difference (LSD) ( $\mathrm{p}<0.05)$. Abbreviations: A; $\mathrm{L}<30,+\mathrm{a},+\mathrm{b} ; \mathrm{B} ; \mathrm{L}<30,+\mathrm{a}$, -b, C; L > 50, +a, +b, D; L > 50, +a, -b

group $\mathrm{B}(\mathrm{L}<30,+\mathrm{a},-\mathrm{b})$ had the highest concentration of total phenolic compounds, whereas group $\mathrm{C}(\mathrm{L}>50$, $+\mathrm{a}$, + b) showed the lowest concentration (Fig. 5, Table 5).

In this study, adzuki bean showed the highest concentration of total phenolic compounds in seeds with low lightness values (near black color). A previous study reported that dark colored (black, red, bronze) legumes possess significantly higher phenolic contents than yellow, green or white colored ones. These results suggest that antioxidant activity was strongly correlated with total phenolic content and confirm that total phenolic content is reasonably correlated with seed hull surface color (Xu et al., 2007). Another study showed that black and red beans have the highest antioxidant activities, whereas white bean has weak antioxidant activity (Madhujith et al., 2004; Madhujith and Shahidi, 2005). Therefore, it can be concluded that genetic factors such as seed weight, seed color, and other environmental factors influenced the synthesis and accumulation of phenolic compounds in adzuki bean seeds.

In this study, the average total phenolic content of the small adzuki bean varieties was higher than that of the medium and large varieties. The phenolic compounds were compressed in the small seeds but dispersed at low density in the large sized seeds. Further, the concentration of phenolic compounds was correlated with seed color values. 
Table 5. Average total phenolic content according to color.

\begin{tabular}{|c|c|c|}
\hline Color group & & Total concentration \\
\hline \multirow{6}{*}{$\mathrm{A}^{1)}$} & Number of variety & 54 \\
\hline & Maximum $\left(\mu \mathrm{g} \mathrm{g}^{-1}\right)$ & 5642.3 \\
\hline & Minimum $\left(\mu \mathrm{g} \mathrm{g}^{-1}\right)$ & 523.8 \\
\hline & Mean $\left(\mu \mathrm{g} \mathrm{g}^{-1}\right)$ & 2439.1 \\
\hline & CV (\%) & 5.7 \\
\hline & $\operatorname{LSD}_{(0.05)}$ & 279.4 \\
\hline \multirow{6}{*}{$\mathrm{B}^{2)}$} & Number of variety & 26 \\
\hline & Maximum $\left(\mu \mathrm{g} \mathrm{g}^{-1}\right)$ & 6597.0 \\
\hline & Minimum $\left(\mu \mathrm{g} \mathrm{g}^{-1}\right)$ & 1689.0 \\
\hline & Mean $\left(\mu g g^{-1}\right)$ & 2826.9 \\
\hline & CV (\%) & 37.7 \\
\hline & $\operatorname{LSD}_{(0.05)}$ & 2190.5 \\
\hline \multirow{6}{*}{$\mathrm{C}^{3)}$} & Number of variety & 51 \\
\hline & Maximum $\left(\mu \mathrm{g} \mathrm{g}^{-1}\right)$ & 5242.5 \\
\hline & Minimum $\left(\mu g g^{-1}\right)$ & 413.3 \\
\hline & Mean $\left(\mu g g^{-1}\right)$ & 1881.1 \\
\hline & CV (\%) & 7.6 \\
\hline & $\operatorname{LSD}_{(0.05)}$ & 288.1 \\
\hline \multirow{6}{*}{$D^{4)}$} & Number of variety & 18 \\
\hline & Maximum $\left(\mu \mathrm{g} \mathrm{g}^{-1}\right)$ & 5049.6 \\
\hline & Minimum $\left(\mu \mathrm{g} \mathrm{g}^{-1}\right)$ & 374.5 \\
\hline & Mean $\left(\mu g g^{-1}\right)$ & 2184.2 \\
\hline & $\mathrm{CV}(\%)$ & 4.1 \\
\hline & $\operatorname{LSD}_{(0.05)}$ & 188.1 \\
\hline
\end{tabular}

Abbreviations: 1) $\mathrm{L}<30,+\mathrm{a},+\mathrm{b}$; 2) $\mathrm{L}<30,+\mathrm{a},-\mathrm{b}$; 3) $\mathrm{L}$ $>50,+\mathrm{a},+\mathrm{b} ; 4) \mathrm{L}>50,+\mathrm{a},-\mathrm{b}$

\section{ACKNOWLEDGEMENT}

This work was carried out with the support of "Cooperative Research Program for Agriculture Science \& Technology Development (Project No. PJ006983)" Rural Development Administration, Republic of Korea.

\section{REFERENCES}

Amarowicz, R. and R. B. Pegg. 2008. Legumes as a source of natural antioxidants. Eur. J. Lipid Sci. Technol. 110 : 865-878.

Amiot, M. J., A. Fleuriet and J. J. Macheix. 1986. Importance and evolution of phenolic compounds in olive during growth and maturation. J. Agric. Food Chem. 34 : 823-826.

Blekas, G., C. Vassilakis, C. Harizanis, M. Tsimidou and D. Boskou. 2002. Biophenols in table olives. J. Agric. Food Chem. 50 : 3688-3692.
Bouaziz, M., M. Chamkha and S. Sayadi. 2004. Comparative study on phenolic content and antioxidant activity during maturation of the olive cultivar Chemlali from Tunisia. J. Agric. Food Chem. 52 : 5476-5481.

Geil, P. B. and J. W. Anderson. 1994. Nutrition and health implications of dry beans: A review. J. Am.Coll. Nutr. 13 : $549-558$

Kim, J. A., W. S. Jung, S. C. Chun, C. Y. Yu, K. H. Ma, J. G. Gwag and I. M. Chung. 2006. A correlation between the level of phenolic compounds and the antioxidant capacity in cooked-with-rice and vegetable soybean (Glycine max L.) varieties. Eur. Food Res Technol. 224 : 259-270.

Madhujith, T., M. Naczk and F. Shahidi. 2004. Antioxidant activity of commmon beans (Phaseolus vulgaris L.). J. Food Lipids 11 : 220-233.

Madhujith, T. and F. Shahidi. 2005. Antioxidant potential of pea beans (Phaseolus vulgaris L.). J. Food Sci. 70 : 82-90.

Maruyama, C., R. Araki, M. Kawamura, N. Kondo, M. Kigawa, Y. Kawai, Y. Takanami, K. Miyashita and T. Shimomitsu. 2008. Azuki bean juice lowers serum triglyceride concentrations in healthy young women. J. Clin. Biochem. Nutr. 43 : 19-25.

Raffo, A., F. Paoletti and M. Antonelli. 2004. Changes in sugar, organic acid, flavonol and carotenoid composition during ripening of berries of three sea buckthorn (Hippophae rhamnoides L.) cultivars. Eur. Food Res Technol. 219 : 360-368.

Rice-Evans, C. A., N. J. Miller and G. Paganga. 1996. Structure antioxidant activity relationships of flavonoids and phenolic acids. Free Radical Biol Med. 20 : 933-956.

Romero, C., M. Brenes, P. García and A. Garrido. 2002. Hydroxytyrosol 4- $\beta$-D-glucoside, an important phenolic compound in olive fruits and derived products. J. Agric. Food Chem. 50 : 3835-3839.

Shon, M. Y., J. Lee, J. H. Choi, S. Y. Choi, S. H. Nam, K. I. Seo, S. W. Lee, N. J. Sung and S. K. Park. 2007. Antioxidant and free radical scavenging activity of methanol extract of chungkukjang. J. Food Comp. Anal. 20 : 113-118.

Tjahjadi, C., S. Lin and W. M. Breene. 1988. Isolation and characterization of adzuki bean (Vigna anagularis cv. Takara) proteins. J. Food Sci. 53 : 1438-1443.

Wang, H. J. and P. A. Murphy. 1994. Isoflavone content in commercial soybean foods. J. Agric. Food Chem. 42 : 1666-1673.

Xu, B. J., S. H. Yuan and S. K. C. Chang. 2007. Comparative analyses of phenolic composition, antioxidant capacity, and color of cool season legumes and other selected food legumes. J. Food Sci. 72 : S167-S177.

Yoshida, H., N. Yoshida, Y. Tomiyama, M. Sakai and Y. Mizushina. 2008. Distribution profiles of tocopherols and fatty acids of phospholipids in adzuki bean (Vigna algularis). J. Food Lipids 15 : 209-221. 
Appendix 1. Characteristics of adzuki bean germplasm.

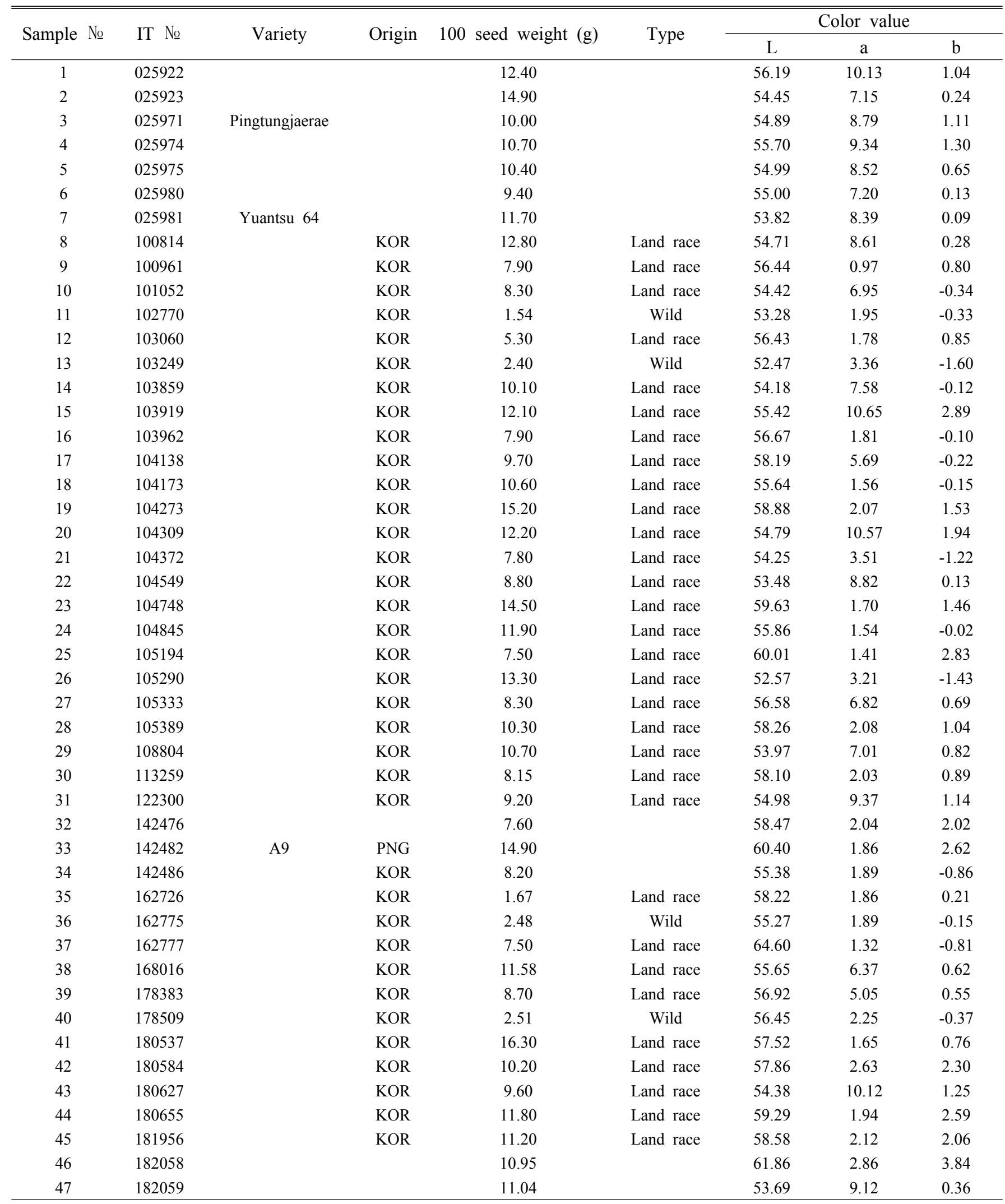


Appendix 1. (Continued)

\begin{tabular}{|c|c|c|c|c|c|c|c|c|}
\hline \multirow{2}{*}{ Sample № } & \multirow{2}{*}{ IT № } & \multirow{2}{*}{ Variety } & \multirow{2}{*}{ Origin } & \multirow{2}{*}{100 seed weight $(\mathrm{g})$} & \multirow{2}{*}{ Type } & \multicolumn{3}{|c|}{ Color value } \\
\hline & & & & & & $\mathrm{L}$ & $\mathrm{a}$ & $\mathrm{b}$ \\
\hline 48 & 182087 & & & 8.49 & & 55.19 & 10.80 & 1.98 \\
\hline 49 & 182089 & & & 9.50 & & 55.39 & 10.17 & 1.26 \\
\hline 50 & 182092 & & & 10.50 & & 54.56 & 9.71 & 1.48 \\
\hline 51 & 182093 & & & 10.50 & & 54.60 & 9.28 & 0.85 \\
\hline 52 & 182095 & & & 12.12 & & 55.94 & 10.49 & 1.31 \\
\hline 53 & 183275 & & & 11.20 & & 56.03 & 9.88 & 1.22 \\
\hline 54 & 183276 & & & 18.15 & & 55.61 & 10.44 & 2.13 \\
\hline 55 & 183278 & ID6W & & 13.40 & & 54.39 & 10.66 & 0.88 \\
\hline 56 & 183292 & & & 16.25 & & 56.03 & 10.38 & 2.51 \\
\hline 57 & 183297 & '92AP14 & & 12.59 & & 56.72 & 9.96 & 2.25 \\
\hline 58 & 183302 & & & 11.12 & & 53.98 & 8.45 & -0.11 \\
\hline 59 & 183308 & & & 12.40 & & 53.36 & 6.48 & -0.67 \\
\hline 60 & 183309 & & PRK & 19.40 & & 55.57 & 1.61 & -0.44 \\
\hline 61 & 186306 & & KOR & 10.40 & Land race & 54.47 & 10.02 & 1.32 \\
\hline 62 & 189416 & & MYS & 11.20 & & 60.64 & 5.53 & 0.35 \\
\hline 63 & 195176 & & KOR & 12.90 & Land race & 54.48 & 8.81 & 0.83 \\
\hline 64 & 195222 & & KOR & 13.60 & Land race & 62.97 & 4.30 & 0.32 \\
\hline 65 & 203423 & & AUS & 12.20 & & 55.19 & 9.21 & 0.59 \\
\hline 66 & 209432 & & NPL & 18.20 & & 55.54 & 8.56 & 0.60 \\
\hline 67 & 209444 & & & 15.20 & & 38.95 & 1.65 & -1.93 \\
\hline 68 & 211855 & & KOR & 11.70 & Land race & 55.30 & 9.55 & 0.83 \\
\hline 69 & 211857 & & & 22.20 & & 56.88 & 8.67 & 1.50 \\
\hline 70 & 212898 & & $\mathrm{CHN}$ & 14.90 & & 25.23 & 5.12 & 0.50 \\
\hline 71 & 215376 & & JPN & 12.20 & Improved & 26.96 & 0.84 & 0.64 \\
\hline 72 & 215444 & & KOR & 2.10 & Wild & 27.15 & 0.91 & 0.52 \\
\hline 73 & 215446 & & KOR & 2.10 & Wild & 26.56 & 0.97 & 0.38 \\
\hline 74 & 215454 & & KOR & 2.20 & Wild & 26.84 & 0.95 & 0.39 \\
\hline 75 & 215457 & & KOR & 2.20 & Wild & 26.69 & 0.98 & 0.66 \\
\hline 76 & 216232 & & KOR & 2.20 & Wild & 24.88 & 1.05 & -0.24 \\
\hline 77 & 216285 & & JPN & 5.40 & Land race & 23.93 & 1.01 & -0.63 \\
\hline 78 & 216286 & & JPN & 2.60 & Land race & 29.97 & -0.22 & 4.99 \\
\hline 79 & 216287 & & JPN & 4.90 & Land race & 26.33 & 7.40 & 1.40 \\
\hline 80 & 216288 & & JPN & 18.10 & Land race & 25.23 & 0.49 & 0.28 \\
\hline 81 & 216289 & & JPN & 4.00 & Land race & 25.51 & 0.54 & 0.27 \\
\hline 82 & 216290 & & JPN & 3.80 & Land race & 24.58 & 1.14 & -0.01 \\
\hline 83 & 216291 & & JPN & 3.60 & Land race & 25.16 & 3.62 & 0.54 \\
\hline 84 & 216292 & & JPN & 6.40 & Land race & 27.08 & 7.78 & 2.26 \\
\hline 85 & 216293 & & JPN & 23.20 & Land race & 26.05 & 7.21 & 1.50 \\
\hline 86 & 216294 & & JPN & 17.80 & Land race & 25.63 & 0.94 & 0.35 \\
\hline 87 & 216295 & & JPN & 5.10 & Land race & 25.70 & 5.94 & 1.27 \\
\hline 88 & 216296 & & JPN & 18.20 & Land race & 26.20 & 7.04 & 1.97 \\
\hline 89 & 216297 & & JPN & 15.60 & Land race & 24.73 & 1.11 & -0.25 \\
\hline 90 & 216298 & & JPN & 3.40 & Land race & 25.09 & 0.95 & 0.28 \\
\hline 91 & 216299 & & JPN & 2.70 & Land race & 24.73 & 0.94 & 0.02 \\
\hline 92 & 216300 & & JPN & 3.70 & Land race & 25.09 & 1.09 & 0.08 \\
\hline 93 & 216301 & & JPN & 2.60 & Land race & 26.47 & 5.54 & 1.36 \\
\hline 94 & 216302 & & JPN & 15.30 & Land race & 24.85 & 1.21 & 0.35 \\
\hline
\end{tabular}


Appendix 1. (Continued)

\begin{tabular}{|c|c|c|c|c|c|c|c|c|}
\hline \multirow{2}{*}{ Sample № } & \multirow{2}{*}{ IT № } & \multirow{2}{*}{ Variety } & \multirow{2}{*}{ Origin } & \multirow{2}{*}{100 seed weight $(\mathrm{g})$} & \multirow{2}{*}{ Type } & \multicolumn{3}{|c|}{ Color value } \\
\hline & & & & & & $\mathrm{L}$ & $\mathrm{a}$ & $\mathrm{b}$ \\
\hline 95 & 216303 & & JPN & 3.60 & Land race & 28.24 & 1.79 & 4.13 \\
\hline 96 & 216304 & & JPN & 3.90 & Land race & 25.06 & 0.69 & 0.25 \\
\hline 97 & 216305 & & JPN & 3.80 & Land race & 25.46 & 0.87 & 0.26 \\
\hline 98 & 216306 & & JPN & 4.00 & Land race & 25.63 & 6.82 & 1.20 \\
\hline 99 & 216307 & & JPN & 14.90 & Land race & 25.34 & 5.29 & 0.96 \\
\hline 100 & 216308 & SHOUNAGON & JPN & 11.70 & Land race & 26.97 & 10.21 & 2.44 \\
\hline 101 & 216309 & CHUUNAGON & JPN & 15.10 & Land race & 25.96 & 6.02 & 0.86 \\
\hline 102 & 216355 & & KOR & 15.60 & Improved & 25.80 & 5.56 & 0.47 \\
\hline 103 & 216356 & & KOR & 18.40 & Improved & 24.06 & 0.94 & -0.77 \\
\hline 104 & 216517 & & JPN & 2.60 & Wild & 24.93 & 0.94 & -0.40 \\
\hline 105 & 216518 & & JPN & 2.50 & Wild & 24.56 & 1.04 & -0.57 \\
\hline 106 & 216519 & & JPN & 2.20 & Wild & 24.17 & 0.96 & -1.07 \\
\hline 107 & 216520 & & JPN & 2.00 & Wild & 24.15 & 0.92 & -0.54 \\
\hline 108 & 216521 & & JPN & 2.40 & Wild & 25.42 & 0.87 & -0.07 \\
\hline 109 & 216522 & & JPN & 2.00 & Wild & 25.26 & 0.99 & 0.16 \\
\hline 110 & 216523 & & JPN & 2.70 & Wild & 25.06 & 0.95 & 0.23 \\
\hline 111 & 216524 & & JPN & 2.40 & Wild & 24.96 & 0.85 & -0.14 \\
\hline 112 & 216525 & & JPN & 24.40 & Wild & 23.90 & 0.98 & -0.92 \\
\hline 113 & 216526 & & JPN & 2.40 & Wild & 28.79 & 1.54 & 4.15 \\
\hline 114 & 216527 & & JPN & 5.4 & Wild & 25.55 & 3.05 & 0.89 \\
\hline 115 & 216528 & & JPN & 2.30 & Wild & 28.49 & 1.16 & 3.80 \\
\hline 116 & 216529 & & JPN & 2.20 & Wild & 24.83 & 1.18 & -0.19 \\
\hline 117 & 216530 & & JPN & 2.30 & Wild & 24.80 & 0.91 & -0.38 \\
\hline 118 & 216531 & & JPN & 2.00 & Wild & 25.82 & 1.20 & 1.10 \\
\hline 119 & 216532 & & JPN & 2.50 & Wild & 24.10 & 0.99 & -0.80 \\
\hline 120 & 216533 & & JPN & 2.40 & Wild & 25.34 & 1.06 & 0.14 \\
\hline 121 & 216534 & & JPN & 2.80 & Wild & 25.20 & 0.82 & -0.05 \\
\hline 122 & 216535 & & JPN & 2.30 & Wild & 24.66 & 1.04 & -0.24 \\
\hline 123 & 216536 & & JPN & 2.50 & Wild & 24.37 & 0.89 & -0.67 \\
\hline 124 & 216537 & & JPN & 2.50 & Wild & 25.86 & 0.79 & 0.18 \\
\hline 125 & 216538 & & JPN & 2.80 & Wild & 25.66 & 1.13 & 0.52 \\
\hline 126 & 216539 & & JPN & 2.70 & Wild & 24.63 & 0.97 & -0.17 \\
\hline 127 & 216540 & & JPN & 2.60 & Wild & 25.37 & 1.06 & 0.33 \\
\hline 128 & 216541 & & JPN & 2.70 & Wild & 25.91 & 0.98 & 0.32 \\
\hline 129 & 216542 & & JPN & 3.70 & Wild & 24.63 & 0.97 & -0.45 \\
\hline 130 & 216543 & & JPN & 2.70 & Wild & 24.41 & 0.96 & -0.35 \\
\hline 131 & 216544 & & JPN & 3.70 & Wild & 28.55 & 1.02 & 3.73 \\
\hline 132 & 216545 & & JPN & 2.90 & Wild & 29.75 & 0.77 & 5.12 \\
\hline 133 & 216546 & & JPN & 3.10 & Wild & 24.78 & 0.98 & -0.22 \\
\hline 134 & 216547 & & JPN & 2.10 & Wild & 26.01 & 4.57 & 0.40 \\
\hline 135 & 216962 & & $\mathrm{CHN}$ & 12.10 & & 26.60 & 7.04 & 0.95 \\
\hline 136 & 217333 & & $\mathrm{CHN}$ & 18.50 & Improved & 25.72 & 1.07 & 0.38 \\
\hline 137 & 217579 & & KOR & 1.80 & Wild & 24.66 & 1.21 & -0.21 \\
\hline 138 & 217580 & & KOR & 1.50 & Wild & 27.01 & 1.48 & 1.33 \\
\hline 139 & 217581 & & KOR & 3.20 & Wild & 25.19 & 1.03 & 0.08 \\
\hline 140 & 217582 & & KOR & 1.70 & Wild & 30.41 & 2.22 & 5.37 \\
\hline 141 & 218027 & & JPN & 3.20 & Land race & 27.09 & 1.84 & 2.57 \\
\hline
\end{tabular}


Appendix 1. (Continued)

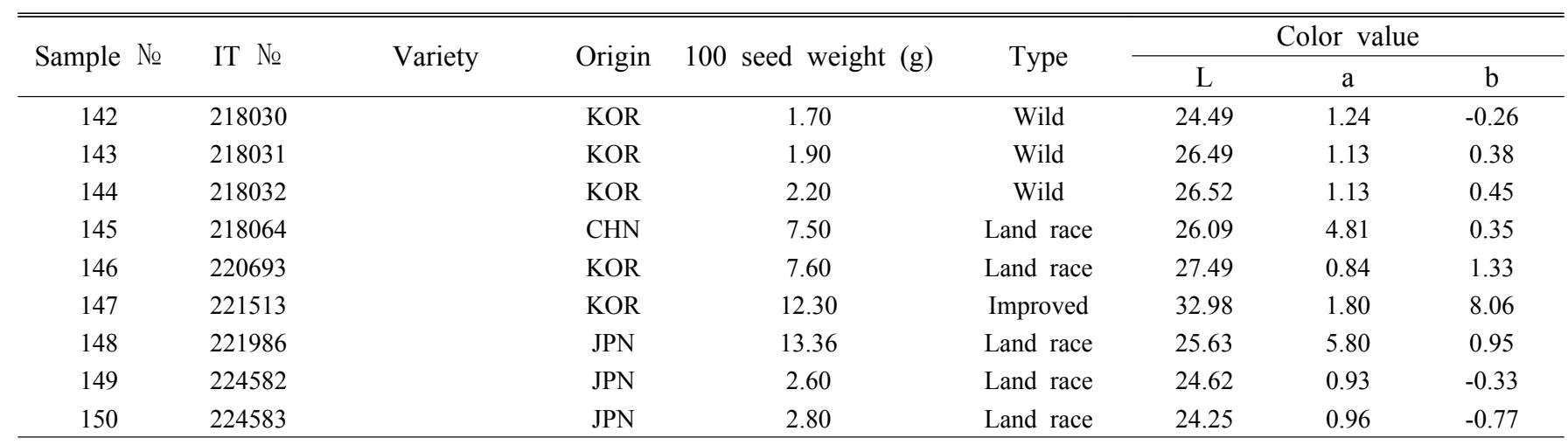

